\title{
Impact of Health Literacy Multimedia Package (HLMP) in improving Awareness on Job-Related Diseases: A case study in Kerala, India
}

\author{
Dr. Divya C. Senan \\ (Department of Education, SreeNarayana Training College, Nedunganda, Kerala, India)
}

\begin{abstract}
This study aimed in determining the effectiveness of Health Literacy Multimedia Package (HAMP) in improving the health awareness level on occupational diseases of the women engaged in coir industry. A survey along the coastal belt of Kerala found that the unhygienic conditions prevailing around the area results in health hazard problems to the people engaged in coirindustry. Since they are spending almost the whole day in the unhygienic conditions prevailing in the yard they are at a high risk of developing occupational diseases. Their lack of knowledge about health and hygiene serves as the prime reason for the contagious diseases. Hence there arose the need to make them aware of the various health hazards, its causes and effects. The search for a strategy which enables to give them awareness regarding health education results in an awareness program through a developed multimedia named Health Literacy Multimedia Package. The package enabled individuals and communities to modify risks caused by unhealthy lifestyle, behaviour and the environment. The package is a ready available material for any instructor giving awareness in the area of occupational health for those working in coir industry.
\end{abstract}

Keywords: Coir industry, Health awareness, Health Literacy Multimedia Package, Job-related diseases

\section{Introduction}

India is a vast country with a surface area of about 3.3 million square $\mathrm{km}$. About $72 \%$ of the population lives in rural area. India is a developing nation and presents the demographic features similar to the other developing nations of the world. Growing population is the major concern of the government and is considered as the principal obstacle to the economic growth of the country. Emerging occupational health problems are to be tackled along with the existing traditional public health problems like communicable diseases, malnutrition, poor environmental sanitation and inadequate medical care. Globalization and rapid industrial growth (about 7\% annual economic growth) in the last few years have further complicated the occupational health related issues.

The major occupational diseases/morbidity of concern in India are silicosis, musculo-skeletal injuries, coal workers' pneumoconiosis, chronic obstructive lung diseases, asbestosis, byssinosis, pesticide poisoning and noise induced hearing loss. Among the various economic sectors a significant but unnoticed sector which causes many occupational diseases is the coir industry.

Coir Industry in India has a very long history. Even the $11^{\text {th }}$ Century A.D. Arab writers have mentioned about Coir and referred to the use of this material for ship's cables, fenders, rigging etc. During the Thirteenth century, there was an evidence of coir yarn being used for ship-building in the Persian Gulf. The remarkable international correspondent of ancient times, Marco Polo, was impressed by its usage there and later on visited the land where Arabs bought their coir and recorded as to how it was made out of a fibre extracted from the coconut husk. Coir industry is concentrated mainly in the coastal belt of Kerala, Tamil Nadu, Andhra Pradesh and Orissa. The 10 coastal districts account for nearly 90 per cent of the total production in Kerala, the southernmost state in India. In fact till the early decades of the last century the industrial development in Kerala, was mostly centred on coconuts. Production of coir yarn and fibre quietly spread through the coastal belt of Kerala utilizing the abundant and cheap labour that was available. Coir weaving industry was localized in and around the coastal areas of the state. Coir industry is one of the traditional industries of Kerala. This industry is described to be traditional, not merely in reference to its historical traditions but also in reference to their traditional technology base that continues to be handcrafted.

\section{Context Of The Problem}

Kerala coast is strikingly bordered by a string of backwaters, generally running parallel to the shoreline. These water bodies locally known as Kayals occupy extensive areas. The size of these water bodies is significantly varied. Out of the 29 backwaters of the Kerala coast, seven are characteristically river mouth estuaries. The backwaters of Kerala provide water front for several major and small scale industries, amongst which coir retting industry ranks first. This industry provides employment to a large number of people, especially women folk. The raw material for the industry is obtained by immersing the husk in water for 8-9 
months. Here, mainly conventional methods of retting are practiced. Retting of husk presents unique and extremely serious problems along the coastal belt, changing the hydro ecology of the water body. Besides the ecological degradation caused by the liberation of organic wastes during the retting process, the unhygienic conditions prevailing around the area results in health hazard problems to the people engaged in this cottage industry. A vast number of rural populations of coastal Kerala are engaged in retting industry, irrespective of their age. They find this work as the source of their principle income. Male members are associated with coolie work connected with coir industry, agriculture and fishing. The most striking aspect of the retting industry is that the workers in the retting site spent almost the whole day in the unhygienic conditions prevailing in the yard and find hardly any time to spare for other educational and cultural activities. The wages given to them are very low compared to their hard work. As a natural consequence their living conditions are never improved. Their financial and epidemiological conditions remain to be very low. The area around the retting yards is inhabited mainly by the community engaged in coir industry. Hence, job related diseases are likely to occur among these people. In the retting sites, aquatic pollution is caused due to organic wastes like lignin, tannin and polyphenols. Low $\mathrm{pH}$ and oxygen content, high BOD, chloride and alkalinity leads to anoxic conditions, adversely affecting the flora and fauna. Air pollution also prevails in these areas due to the release of hydrogen sulphide, methane and carbon dioxide. Common diseases likely to occur among the people are filariasis, eye diseases, skin diseases, oedema of lungs and headache due to the inhalation of poisonous gases.

\section{Review Of Research And Development In The Subject}

The review of literature involves the systematic identification, location and analysis of documents which include periodicals, abstracts, reviews, books and other research reports. The major purpose of reviewing the literature is to determine what has already been done that relates to the thrust area of a study. It also points out research strategies and specific procedures and measuring instruments that have and have not been found to be productive in investigating the problem (Gay, 1996).

Uragoda.C.G (1975) made a clinical and radiographic study of coir workers. He reported in the British Journal of Industrial medicine that respiratory diseases such as asthma bronchitis, bysinossis, and pulmonary tuberculosis occurred due to occupational exposure. FeizalSamath (2008) wrote a paper on Spinning Livelihoods from Coir Fibre.Sabu Thomas, H. Harikrishnan\&Sandhya.C.Nair (2006) studied the molecular analysis of bacterial population inhabiting coconut husk retting area. The existence of supplied system in the retting zone and the seasonal variation in abundance of the Crustacean fauna, in comparison with the nonretting area were discussed by Abdul Aziz et al., 1982.Environmental pollution due to retting of coconut husk and preliminary studies on closed system retting has been studied by Abbassi, et al., 1982. The retting of coconut husks in the backwaters is brought about by the pectin lytic activity of microorganisms, especially bacteria and fungi, degrading the fibre-binding material of the husk and liberating large quantities of organic substances including pectin, pentosan, fat and tannin into the ambient water. Microbiological studies of few coconut retting areas were carried out by Jayasankar\&Menon, 1961. Retting activities carried out in anaerobic system were studied by Bhatt, 1969. Effects of retting on water quality and ecosystem of the estuaries of Kerala has been studied in detail by various scientists. The impact of retting on the fishery wealth was studied by Abdul Azis and Balakrishnan Nair, 1978. Organic carbon and organic matter showed enrichment in the retting ground sediments. The $\mathrm{C} / \mathrm{N}$ ratios were constituently higher in the retting yard. Annual average of bacterial biomass was higher in the non-retting yard $(25.7 \mathrm{mg} / \mathrm{g})$ as against $22.8 \mathrm{mg} / \mathrm{g}$ in the retting yard. Ecology of the Akathumuri, Anjengo and Kadinamkulam Lake and its physicochemical conditions were studied by Balakrishnan Nair. N,(1983). Meiofauna of Edava - Nadayara backwater system, south-west coast of India was studied. Ecology and distribution of benthic macro fauna in the Ashtamudi Estuary of Kerala was attempted by Balakrishnan Nair. N. Et al., 1984.Impact of retting industry on the fauna and flora of the backwater system was studied by Remani and Nirmala, (1989).

\section{Measuring The Effectiveness Of Health Literacy Multimedia Package (Hamp)}

As a part of the curricular studies the student teachers of our college went for a survey in Anjengopanchayath, a coastal village in Kerala, India where women are engaged in coir retting and coir making. They collected data regarding the health condition as well as socio economic conditions of the inhabitants. It was found that the unhygienic conditions prevailing around the area results in health hazard problems to the people engaged in this cottage industry. Majority of the women are engaged in retting industry, irrespective of their age. Since they are spending almost the whole day in the unhygienic conditions prevailing in the yard they are at a high risk of developing occupational diseases. Their lack of knowledge about health and hygiene serves as the prime reason for the contagious diseases. From review of related studies it was revealed that the coir retting industry is an activity that is intricately interwoven with the social and economic structure. Field survey results indicated that $57 \%$ of the sample suffered from job-oriented disease like skin disease, blindness, headache, back bone pains and respiratory disease. Rotted husk release more organic pollutants and they highly 
affect the water quality parameters. Therefore, it is a difficult task to save these women from these occupational hazards unless some new affordable technique is introduced. Majority of the households (70 \%) fall within a low socio-economic status with a deepening poverty background depicted by low educational achievement and occupational status. Hence there arise the need to make them aware of the various health hazards, its causes and effects. The search for a strategy which enables to give them awareness regarding health education results in an awareness program using a multimedia package. As a result the investigator designed and developed a multimedia package named Health Literacy Multimedia Package (HAMP) to provide health awareness on occupational diseases related to coir industry. Hence this study aims to determine the effectiveness of Health Literacy Multimedia Package (HAMP) in improving the health awareness level on occupational diseases of the women engaged in coir industry.

\section{Methodology}

The plurality of process calls for multiple methodologies which include both Survey and Experiment. Hence, it was decided to divide this into two sections.

Descriptive section: For analysing existing awareness level of women coir workers on the occupational diseases, its health hazards and various remedial measures. Survey was the method used in this section of the study. An occupational disease awareness inventory was used to collect data. It was conducted to find out the existing awareness level of women coir workers regarding occupational diseases and its health hazards.

Experimental section: For assessing the effectiveness of Health Literacy Multimedia Package. Since the main objective of the present study was to assess the effectiveness of Health Literacy Multimedia Package, the experimental method was adopted for the study. In conducting the experiment for the study, the design adopted was single group pre-test post-test design.

\subsection{Instruments}

The tools used in the present study are

i. Health Literacy Multimedia Package (HLMP)

ii. Occupational Disease Awareness inventory

iii. Questionnaire to analyze the extent of health awareness regarding occupational disease related to coir industry.

\subsection{Participants' selection process}

A suitable sample of women coir workers of Kerala, India was selected. Random sampling method was used.

\subsection{Pre-Test conducted}

\section{Procedure Adopted In Experimentation}

Before starting the experiment, the investigator administered the prepared Questionnaire to analyze the extent of health awareness regarding occupational disease related to coir industry to the target group. In the administration of the test, the investigator personally read the questions for the target group.

\subsection{Awareness campaign to the Target Group with the help of multimedia learning package}

Awareness campaign is an effective way of communication to the mass, since such programmes are highly relevant in transferring research / extension / management aspects to the public. Awareness camps were conducted in various Wards of Anchuthengu Panchayat. Through awareness classes target groups were informed and disseminated scientific knowledge about occupational diseases and its control.

The major segment of the rural community, who assembled in the awareness camps conducted in the various Wards of the target sites were women. Through discussions and demonstration classes with the help of multimedia package, they were educated on the various components related occupational diseases. The multimedia package consists of text information ideally supported by graphics which is preferably presented to provide information in an appealing and easily understood manner. Health Literacy Multimedia Packagewas distributed among the target groups who attended the 'Awareness Camps'.

\subsection{Post test Conducted}

After the completion of awareness campaign post-test (Questionnaire to analyze the extent of health awareness regarding occupational disease related to coir industry) was conducted by the investigator for the target group 


\section{Data Analysis}

7.1 Section i: Extent of Awareness on Occupational Diseases and its Remedial Measures.

The objectives which are to be realised in this section are:

1. To find out the extent of awareness on occupational diseases and its remedial measures among the women coir workers of Kerala, India.

2. To develop a Health Literacy Multimedia Package (HAMP) for providing awareness on health education related to occupational disease due to coir retting.

The extent of occupational health awareness was found out through a survey. An Inventory (constructed and standardised by the investigator) based on health education under the select three dimensions was used to collect relevant data. Ratings of women coir workers were collected; frequency and percentage of responses of the select three dimensions were computed. Details are given in the relevant tables:

- Ratings of women coir workers regarding their extent of awareness on job related diseases

In order to find the extent of awareness percentages of responses of the select coir workers were computed. Details are given in Table.

Table I: Responses of Coir Workers Regarding their Awareness on Job Related Diseases

\begin{tabular}{|c|c|c|c|c|c|}
\hline Dimension & $\begin{array}{c}\text { Unaware } \\
\%\end{array}$ & $\begin{array}{c}\text { Aware to some } \\
\text { extent } \\
\%\end{array}$ & $\begin{array}{c}\text { Aware to a certain } \\
\text { extent } \\
\%\end{array}$ & $\begin{array}{c}\text { Aware to a great } \\
\text { extent } \\
\%\end{array}$ & $\begin{array}{c}\text { Aware } \\
\%\end{array}$ \\
\hline $\begin{array}{c}\text { Awareness on job- } \\
\text { related diseases }\end{array}$ & 18.70 & 57.61 & 21.80 & 1.82 & 0.07 \\
\hline
\end{tabular}

From Table I, it is clear that women coir workers of Kerala are unaware of occupational diseases and its effects. As far as the responses in the table were concerned, more than fifty percent (57.61\%) don't know about the various occupational as well as communicable diseases and nearly one-fifth $(18.70 \%)$ of the coir workers know about these diseases to some extent. Almost the same percentage $(21.80 \%)$ of the coir workers have heard about such diseases and it was also noted that only a negligible percentage of coir workers marked their responses as aware to a great extend $(1.82 \%)$ and aware $(0.07 \%)$.

The above responses indicated that almost all the workers selected for the study do not have knowledge on the various occupational diseases. To overcome this problem, specific awareness programmes for enhancing the awareness of workers on various job related diseases need to be designed.

- Ratings of women coir workers regarding their extent of awareness on health hazards of job related diseases

In order to identify the extent of prevailing awareness level of coir workers on the health hazards of occupational diseases the percentages of were computed. The details are given in Table below

Table II: Responses of Women Coir Workers Regarding their Extent of Awareness on the Health Hazards of Job Related Diseases

\begin{tabular}{|c|c|c|c|c|c|}
\hline Dimension & $\begin{array}{c}\text { Unaware } \\
\%\end{array}$ & $\begin{array}{c}\text { Aware to some } \\
\text { extent } \\
\%\end{array}$ & $\begin{array}{c}\text { Aware to a } \\
\text { certain extent } \\
\%\end{array}$ & $\begin{array}{c}\text { Aware to a great } \\
\text { extent } \\
\%\end{array}$ & $\begin{array}{c}\text { Aware } \\
\%\end{array}$ \\
\hline $\begin{array}{c}\text { Awareness of } \\
\text { health hazards of } \\
\text { job-related } \\
\text { diseases }\end{array}$ & 32.68 & 43.03 & 17.96 & 5.81 & 0.52 \\
\hline
\end{tabular}

The results of Table II revealed that though the women coir workers are suffering from such diseases they are unable to identify the health hazards of these diseases. While considering the responses of the select sample, majority (43.03\%) of the coir workers are unaware of the various health hazards of coir dyes and coir piths while most of the sample selected (32.68\%) opined that they are aware of the health hazards to some extent. A small proportion of coir workers (17.96\%) are aware of the various effects of occupational diseases to certain extend and a few $(5.81 \%)$ are aware of it to a great extent. It was also noted that a negligible percentage $(0.52 \%)$ of coir workers 'are aware of all the health hazards of working in coir industry.

- Ratings of women coir workers regarding their extent of awareness on the remedial measures

To find the extent awareness on the remedial the percentages of responses of the select coir workers were computed. The details are given in Table 
Table III: Responses of Women Coir Workers Regarding their Extent of Awareness on the Remedial

\begin{tabular}{|c|c|c|c|c|c|}
\hline \multicolumn{9}{|c|}{ Measures } \\
\hline Dimension & $\begin{array}{c}\text { Unaware } \\
\%\end{array}$ & $\begin{array}{c}\text { Aware to some } \\
\text { extent } \\
\%\end{array}$ & $\begin{array}{c}\text { Aware to a } \\
\text { certain extent } \\
\%\end{array}$ & $\begin{array}{c}\text { Aware to a great } \\
\text { extent } \\
\%\end{array}$ & $\begin{array}{c}\text { Aware } \\
\%\end{array}$ \\
\hline $\begin{array}{c}\text { Awareness on the } \\
\text { remedial } \\
\text { measures }\end{array}$ & 45.85 & 43.50 & 10.50 & 0.15 & 0.00 \\
\hline
\end{tabular}

While analysing the results obtained from Table III, it was found that nearly half $(45.85 \%)$ of the selected coir workers are unaware of the remedial measures to avoid occupational diseases to a certain extent, and almost an equal percentage (43.50\%) of coir workers are aware of remedial measures only to some extent. Very few coir workers $(10.50 \%)$ are aware of it to certain extend, while a negligible percentage $(0.15 \%)$ of coir workers are aware of the remedial measures to a great extent. It was surprisingly noted that none of the coir workers in the select sample are aware of the various remedial measures for occupational diseases.

The alarming percentage of negative responses as per Table indicates the urgent need of chalking out an awareness programme to conscientise coir workers about the occupational disease, its effect and various remedial strategies which can be practiced to avoid such job related diseases to certain extend. Hence the investigator decided to design and develop a ready to use package on Health Education named Health Literacy Multimedia Package (HAMP)to make the women coir workers aware of all the health hazards caused due to their occupation.

\subsection{Section-ii: Effectiveness of the Health Literacy Multimedia Package (HAMP)}

After identifying the areas of awareness needed investigator tried to design and develop a Health Literacy Multimedia Package (HAMP)with the help of a graphical designer. Interviews were conducted with expert doctors in the field.

The main thrust of this section is to identify the effectiveness of the developed Health Literacy Multimedia Package (HAMP)on Health Awareness.

The objective which is to be realized in this section is:

To find the effectiveness of developed Health Literacy Multimedia Package (HAMP)on Health Awareness of Occupational Diseases due to Coir Retting.

For the purpose the investigator compared pre-test and post-test scores of the target groups using t-test. The details are as follows.

- Comparison of the pre-test and post-test scores of participants on the health awareness

The mean and standard deviation of pre-test and post-test scores of the select sample in the experimental group were computed and the effectiveness of Health Literacy Multimedia Package (HAMP)on awareness of occupational diseases are found out by computing the critical ratio. Table presents the data and results of the test of significance.

Table IV: Data and results of the Test of Significance of Difference between the Mean Pre-test and Posttest Scores of the Participants in the Experimental Group

\begin{tabular}{|c|c|c|c|c|}
\hline Test & $\mathrm{N}$ & Mean & $\begin{array}{c}\text { Standard } \\
\text { Deviation }\end{array}$ & Critical Ratio \\
\hline $\begin{array}{l}\text { Pre-test } \\
\text { Post-test }\end{array}$ & $\begin{array}{l}94 \\
94\end{array}$ & $\begin{array}{l}20.61 \\
60.34\end{array}$ & $\begin{array}{l}3.53 \\
8.28\end{array}$ & $42.79 * *$ \\
\hline
\end{tabular}

The critical ratio was 42.79. Entering Table D with $186 \mathrm{df}$, we find that the critical ratios at 0.05 and 0.01 levels were to be 1.97 and 2.80 respectively. The obtained critical ratio was higher than 2.80 . Hence, the obtained difference was significant beyond 0.01 levels. This indicates that the pre and post-test on health awareness on occupational diseases of experimental group differed significantly. Since the mean score of the post-test was higher than that of the pre-test, the experimental group performed well in the post-test on health awareness. So, it can be concluded that the Health Literacy Multimedia Package (HAMP)was effective in enhancing awareness on coir workers on the health hazards of occupational diseases and its remedial measures.

\section{Conclusions Based On The Findings Of The Study}

The conclusions that emerged from the results of the analysis of data are given under two sections.

Section I: Extent of health awareness on occupational diseases related to coir industry and its remedial measures.

Section II: Effectiveness of the Health Literacy Multimedia Package (HAMP) for health education among the women coir workers of Kerala 


\subsection{Conclusion 1}

The prevailing health awareness level of women coir workers regarding occupational diseases is not satisfactory in all the select three dimensions.

This is supported by the following findings of the study:

a) Only a small percentage of coir workers were found to be aware of various occupational diseases (percentages ranged from 0 to 7.18), while the majority of the coir workers were found to be ignorant about the various occupational as well as communicable diseases.

b) Majority (43.03\%) of the coir workers are unaware of the various health hazards of coir dyes and coir piths while most of the sample selected $(32.68 \%$ ) opined that they are aware of the health hazards to some extent. A small proportion of coir workers $(17.96 \%)$ are aware of the various effects of occupational diseases to certain extend and a few (5.81\%) are aware of it to a great extent. It was also noted that a negligible percentage $(0.52 \%)$ of coir workers 'are aware of all the health hazards of working in coir industry.

c) While analysing the results it was found that nearly half $(45.85 \%)$ of the selected coir workers 'Never' practiced the remedial measures to avoid occupational diseases to a certain extent, and almost an equal percentage $(43.50 \%)$ of coir workers 'Rarely' practiced the same. Very few coir workers $(10.50 \%)$ 'Sometimes' practised them, while a negligible percentage $(0.15 \%)$ of coir workers 'Often' practiced the remedial measures. It was surprisingly noted that none of the coir workers in the select sample 'Always' practiced the various remedial measures.

\subsection{Conclusion - 2}

The developed Health Literacy Multimedia Package (HAMP) is effective in enhancing the health awareness level regarding occupational diseases among the women coir workers.

This conclusion is supported by the following findings

When the pre- and post- test scores on health awareness of the experimental group were compared, the critical ratio obtained was found to be significant at 0.01 level $(\mathrm{CR}=42.79 ; \mathrm{p}<0.01)$.

\section{Summary Of The Findings}

The study throws light on the fact that the prevailing health awareness level of women coir workers regarding occupational diseases are not satisfactory in all the select three dimensions. The study also found that the developed Health Literacy Multimedia Package (HAMP) on heath awareness regarding occupational diseases is effective in enhancing the awareness of women coir workers of coastal areas of Kerala.

\section{Review And Recommendations}

Coir retting industry is presently passing through difficult times, mainly due to the scarcity of raw materials, increased price of yarn and products and reduced inflow of orders from abroad. Coir Board in collaboration with the State Government may initiate proper steps for improving the status of this industry.

The premises of the retting yard situated in the Coastal areas of Kerala, are inhabited mainly by the community of people engaged in coir industry. Retting practises cause air and water pollution which adversely affects the community and ecosystem. In most coastal areas one of the major problems faced by the people engaged in retting activity is lack of safe drinking water. Also they need proper sanitation facilities.

Awareness programmes conducted in the various Wards of AnjengoPanchayath has raised their health awareness level regarding occupational as well as communicable diseases. Coir labourers receive very low wages from co-operative societies. It is most striking that worker especially women spent the whole day in the unhygienic conditions of the yard and finds hardly any time to spare for other educational and cultural activities. Low financial conditions compounded with illiteracy make their life miserable. Retting community deserves much support from the Government for the upliftment of their health as well as life status.

\section{Conclusion}

This study examined the health awareness level of coir retting women of coastal areas of Kerala, a state ranked at the top in terms of human development index, social development index and gender development index among the states in India. The state is often described as a land of 'good health at low cost' and is reported to have the lowest rural-urban inequalities in public health status. The present study highlights the need of additional awareness campaign for the women coir workers of coastal areas of Kerala which revealed the need of developing multimedia learning packages which can be used for training. The awareness campaign with the help of developed Health Literacy Multimedia Package (HAMP) proved very effective in empowering the coir retting women. The study also found that the Health Literacy Multimedia Package (HAMP) on heath awareness regarding occupational diseases is effective in enhancing the awareness of women coir workers of coastal areas of Kerala. 


\section{Acknowledgement}

I greatly acknowledge University Grants Commission, New Delhi, India for providing me the financial support needed for the study.

\section{References}

[1] Gay, L. R., Mills, G. E., \&Airasian, P. (2009). Educational research: Competencies for analysis and application (9th Ed.).Upper Saddle River,NJ: Merrill/Pearson Education. [See Chapter 2.]

[2] Uragoda, C.G. (1975). A clinical and radiographic study of coir workers.Br J Ind Med. 1975 Feb; 32(1):66-71.

[3] Feizal, Samath. (2008). SRI LANKA:Spinning Livelihoods from Coir Fibre. Retrieved from http://www.ipsnews.net/2008/10/srilanka-spinning-livelihoods-from-coir-fibre/

[4] Sabu Thomas, K., Harikrishnan.,\&Sandhya, C. Nair. (2006). Molecular Analyis of Bacterial population in Coconut husk retting areas.Indian Journal of Biotechnology, 5: 559-561

[5] Abdul Aziz P.K \&Balakrishnan Nair. N. (1982).Ecology of Crustacean plankton of the retting zone with special reference to sulphide pollution in a backwater system of Kerala.Mahasagar, 15 (3) 1982, pp. 175-183

[6] Abbassi S.A., Remani.K.N. (1982). Environmental pollution due to retting of coconut husk and preliminary studies on closed system retting.Journal of Institution of Engineers, 1982

[7] Jayasankar, N.P., \&Menon, K.P.V. (1961). Microbiological Flora of a few Coconut Retting Areas, Coir, 5, pp. 33 -36.

[8] Bhatt J.V., Prabhu G.N., Kundala K.G., \&Amuja, R. (1969).'Investigations on Anaerobic Retting of Coconut Husk', 3rd International Congress on the 'Global Impacts of Applied Microbiology' Bombay, 39.

[9] Abdul Aziz, P.K.,\&Balakrishnan Nair, N. (1978).The nature of pollution in the retting zones of the backwaters of Kerala.Aquatic Biology, 3, 1978, pp. 41-62.

[10] BalakrishnanNair,N. (1983).Meiofauna of EdavaNadayara backwater system, South West Coast of India.Mahasagar 16, pp. 55-65

[11] Balakrishnan Nair, N., \& Abdul Aziz. (1984). Ecology of Indian Estuaries: Ecology and distribution of benthic microfauna in the Ashtamudi Estuary of Kerala.Mahasagar, 17, pp. 89-101.

[12] Remani, K.N.,\&Nirmala, E. (1989).Assessment of Pollution due to Retting of Coconut husk and Development of Alternative Retting Technology Final Report. CWRDM, 1989 